\title{
Palavra e desejo de mulher: notas sobre lírica e erotismo em Graça Nascimento
}

\author{
Palabra y deseo de mujer: notas \\ sobre lírica y erotismo en Graça \\ Nascimento
}

Marcelo Medeiros da Silva ${ }^{1}$

https://orcid.org/0000-0003-1055-910X

\begin{abstract}
Resumo: O artigo tece reflexões sobre a relação mulher, escrita, erotismo e sexualidade na poesia brasileira a partir da análise da obra de Graça Nascimento, poetisa pernambucana que, nascida na cidade de Canhotinho, vive na penumbra da cena literária nacional, apesar de seu intenso ativismo cultural. O objetivo é pensar como se constrói o discurso erótico na lírica dessa poetisa e evidenciar como tal discurso confere à obra dela uma dicção que, embora com traços próprios, mantém-se em diálogo com o discurso erótico erigido por outras poetisas já consagradas na lírica brasileira que ousaram falar de desejo, sexo, sexualidade a partir de uma perspectiva centrada no feminino. Na consecução de tal objetivo, as reflexões, ao longo do trabalho, respaldam-se nos estudos de Bataille (1987), Hegel (2004), Paz (1994), Soares (1991). Espera-se contribuir para os estudos acerca da produção literária de autoria feminina, em especial para aqueles que procuram refletir sobre como a palavra literária tem servido de esteio para que mulheres possam falar de corpo, desejo e sexualidade, apesar dos interditos sociais.
\end{abstract}

Palavras-chave: Poesia de Autoria Feminina; Erotismo; Sexualidade Feminina.

Resumen: El artículo presenta reflexiones sobre la relación mujer, escritura, erotismo y sexualidad en la poesía brasileña a partir del análisis de la obra de Graça Nascimento, poetisa pernambucana que, nacida en la ciudad de Canhotinho, vive en la penumbra de la escena literaria nacional, a pesar de su intenso activismo cultural. El objetivo es pensar cómo se construye el discurso

\footnotetext{
${ }^{1}$ Doutor em Letras pela Universidade Federal da Paraíba e docente do Programa de Pós-Graduação em Formação de Professores e do curso de Letras do Campus VI da Universidade Estadual da Paraíba. E-mail: marcelomedeiros_silva@yahoo.com.br
} 
erótico en la lírica de esa poetisa y señalar cómo dicho discurso le da a su obra una dicción que, aunque con rasgos propios, se mantiene en diálogo con el discurso erótico erigido por otras poetisas ya consagradas en la lírica brasileña que se atrevieron a hablar sobre deseo, sexo, sexualidad desde una perspectiva centrada en lo femenino. Para lograr este objetivo, las reflexiones a lo largo del trabajo están respaldadas por los estudios de Bataille (1987), Hegel (2004), Paz (1994), Soares (1991). Se espera contribuir para los estudios sobre la producción literaria de autoría femenina, especialmente para aquellos que buscan reflexionar sobre cómo la palabra literaria ha servido como pilar para que las mujeres puedan hablar sobre cuerpo, deseo y sexualidad, a pesar de las restricciones sociales.

Palabras clave: Poesía de Autoría Femenina; Erotismo; Sexualidad Femenina.

\section{INTRODUÇÃO}

Em matéria para o Jornal O Globo ${ }^{2}$, assinada pelo jornalista Bolívar Torres, as escritoras Márcia Denser, Luciana Hidalgo, Simone Campos, Lúcia Bettencourt e Jamyle Hassan Rkain reiteram o quão difícil é encontrar, na literatura brasileira, a representação do desejo erótico a partir de um discurso e de um olhar femininos. Isso, de certa forma, advém do (neo)conservadorismo que se propaga em nossa sociedade desde tempos remotos e que estigmatiza a produção (erótica) de autoria feminina, interditando certos temas às escritoras. A título de exemplificação, consultando a edição da Antologia da poesia erótica brasileira, organizada por Eliane Robert Moraes e publicada em 2015, obra que traz um rol de poemas desde o século XVII até os dias de hoje, temos, no geral, um conjunto de 134 autores incluídos na antologia. Desse número, apenas 11 são mulheres. Desse percentual, três nasceram no século XIX (Alexandrina da Silva Couto dos Santos, Francisca Júlia e Gilka Machado) enquanto as demais (Dora Ferreira da Silva, Hilda Hilst, Adélia Prado, Maria Lúcia Dal Farra, Alice Ruiz, Ana Cristina César, Angela Melin, Cláudia Roquette-Pinto) são do século XX. Esse exemplo aponta para o fato de que a relação mulher, escrita e sexualidade tem sido algo indigesto de modo que elas, em se tratando de desejo, têm, mais uma vez, a sua fala sequestrada.

Na história da literatura brasileira, acerca da relação mulher e desejo, o caso emblemático é o de Gilka Machado, que foi, socialmente, punida porque teve como "glorioso pecado" a ousadia de falar de desejo em uma sociedade repressora, rompendo com "o destino

2 Cf.: https://oglobo.globo.com/cultura/livros/escritoras-reclamam-do-estigma-sobre-literatura-eroticafeminina-22001249? utm source=Facebook\&utm medium=Social\&utm campaign=compartilhar 
rotineiro da mulher-poetisa nacional" (DAL FARRA, 2017, p.18), mas não deixando, de certa forma, de sucumbir aos comentários maldosos que foram deslocando a temática de sua poesia e arrastando a poetisa para certo ostracismo, decretando-lhe, pois, seu suicídio em vida. O exemplo de Gilka Machado mostra-nos que não é de agora que a escrita de mulheres sofre interdições e tem de lutar contra as coerções de ordem moral, social e cultural para poder falar para além de temas determinados previamente por uma sociedade machista e misógina. Há pelo menos mais de quatro décadas, quando a crítica literária feminista aportou no Brasil, começouse a pôr em xeque a nossa tradição literária escrita no e para o masculino e a buscar, em meio à poeira de arquivos, em gavetas de guardados, em velhos criados-mudos, nomes de mulheres e obras escritas por elas. Todo esse trabalho culminou na descoberta de uma verdadeira tradição literária de autoria feminina olvidada porque apenas a produção masculina era socialmente referenciada de maneira que os "escritos de mulher" eram designados como inferiores, menores, pueris, piegas.

Com o advento da crítica literária feminista, vamos aprender uma lição imprescindível ao exercício crítico: voltar-se para uma obra e admirá-la por ter sido escrita por uma mulher não denota uma postura condescendente, mas revela uma postura política cujo objetivo é dar visibilidade à(s) autora(s) e à(s) obra(s) produzida(s) por ela(s). A crítica feminista veio, portanto, descortinar a misoginia do nosso cânone literário e empreender uma busca incessante por obras produzidas por mulheres, evidenciando que as escritoras de outrora sofreram, em seu trabalho nas Letras, do mal da época que incluía a falta de instrução, de direitos legais, o não reconhecimento das mulheres como cidadãs, problemas esses, em parte, solucionados contemporaneamente, mas aos quais se somaram outros que envolvem publicação, circulação, comercialização. Enfim, se, na superfície social, houve mudanças, parece-nos, todavia, que as estruturas hegemônicas de poder mantêm-se inalteradas, visto que, ainda, vivemos em uma sociedade que procura naturalizar a dominação masculina, a violência contra a mulher, a castração do desejo feminino. Se antes a luta era pelo direito de falar e pela visibilização dessa fala, contemporaneamente, o embate é pela manutenção desse direito. No campo literário, assim como em outras esferas sociais, reverbera o mesmo grito que tem arregimentado muitos/as em prol da luta por nenhum direito a menos.

Por isso, mais do que necessário se faz falar de mulher, de desejo, de sexualidade e, mais precisamente, das mulheres que desejam e não se recusam a expressá-lo literariamente, revelando "uma autoconsciência do trabalho criador da mulher", de maneira que "somos conduzidos para uma intenção de reconhecimento desse trabalho como criação feminina, uma vez que o espaço da literatura ainda é, com raras exceções, lugar de afirmação da produção 
masculina" (SOARES, 1999, p. 52). Tendo em vista o exposto, este artigo volta-se para a poesia de Graça Nascimento, poetisa nascida em Canhotinho, agreste de Pernambuco, em 18 de dezembro de 1954. Procuramos compreender como, em sua lírica, erige-se, sem reservas, um discurso de exaltação do sexo a partir de uma óptica centrada no feminino.

\title{
Lírica e erotismo: entrecruzando olhares sobre a poesia de Graça Nascimento
}

Na apresentação que faz a Na nudez da poesia (1991), primeiro livro publicado, Graça Nascimento reitera que, desde pequena, sentia-se compelida a fazer poesia, a qual, por sua vez, é fruto das emoções que brotam das reentrâncias da própria poetisa:

\begin{abstract}
Sempre tive uma certa intimidade com as letras e sempre usei-as como um meio de transmitir para o concreto de um papel o abstratismo do meu sentimento. É como se fosse necessário visualizar a emoção para melhor senti-la. Gosto de ler-me, é como se tivesse sentido-me outra vez, e outra mais, outra mais... A compreensão da universalidade da minha dor e do êxtase, a constatação da existência de milhões de veros presos e milhões de emoções latentes carentes de ecos. A necessidade simplesmente humana de encontrar identificações, me faz editar um livro (NASCIMENTO, 1991, p.03).
\end{abstract}

Ao dizer que sua poesia nasce das emoções que lhe vêm do mais recôndito de seu ser, a poetisa liga-se a uma tradição que vê a poesia lírica como a exteriorização dos estados de alma de um "eu". Nesse processo, ritmo e melodia, em especial, concorrem para que haja, via linguagem, a organização em produto poético desse material nascido da alma: "uma imagem aqui, uma imagem ali, um ritmo cá, uma sonoridade lá, e eis o mergulho numa ilha de existência poética" (CARA 1986, p.60). Isso quer dizer que a lírica é marcada por certa introspecção, a qual, porém, não está imune às injunções históricas. Por isso, adverte Cara (1986, p.61), faz-se necessário "perseguir as relações entre expressão lírica e história, observando seus modos de expressão nos vários momentos".

No entanto, não podemos perder de vista que, como ação individual ante o mundo objetivo, a lírica nasce da visão subjetiva de um sujeito lírico. No dizer de Hegel (2004), a marca da lírica é, pois, a revelação de uma subjetividade, visto que "o campo de expressão e comunicação não se reduz, de modo algum, apenas às manifestações do pensamento lógico" (CARA, 1986, p.42). Consequentemente, a lírica configura-se como a expressão das disposições da alma e dos sentimentos de tal modo que "a disposição a mais fugidia do instante, a exultação 
do coração, os lampejos de amenidades e gracejos despreocupados que rapidamente se apagam", assim como "a tristeza e melancolia, a lamúria, enfim, a gradação inteira do sentimento é retida em seus movimentos momentâneos ou ocorrências subjetivas singulares sobre os objetos mais diversos e é tornada duradoura por meio da expressão" (HEGEL, 2004, p.159).

Considerando-se, portanto, que o conteúdo da lírica faz parte das camadas interiores do sujeito, com seu "estado individual de ânimo, o grau da paixão, a intensidade, a efervescência e a alternância ou o repouso da alma e a quietude da consideração que progride lentamente [...]" (HEGEL, 2004, p.160), na poesia de Graça Nascimento, notamos essa relação íntima entre lírica e erotismo da qual o impulso do desejo se faz linguagem. Por isso, interessanos verificar como se configura o jogo erótico nessa poetisa a fim de evidenciamos a que representações culturais acerca da sexualidade feminina se vincula o discurso erótico construído em sua obra. Para tanto, porém, é preciso pontuarmos o que entendemos por erotismo tendo em vista que:

\footnotetext{
São misteriosos os laços que unem a poesia ao erotismo. Misteriosos e duradouros, já que despertar da lira de Eros parece coincidir com a própria origem das línguas e, desde sempre, seus ecos vibram com intensidade por toda parte. Não admira, pois, que a escrita erótica tenha sido praticada por tantos poetas e que muitos deles tenham interrogado tais segredos para melhor conhecer o pacto entre a carne e a letra. As respostas que nos legaram repercutem, de forma notável, umas nas outras, como que reafirmando as fundações de um saber antigo (MORAES, 2015, p. 18).
}

Como manifestação artística, o erotismo pode ser visto como a representação de uma das mais antigas formas de saber/experiência humana: o desejo sexual. Esse é um fato natural que, segundo Bataille (1987), foi convertido em atividade erótica. Todavia, como assinala o referido autor, "a atividade sexual dos homens não é necessariamente erótica. Ela o é sempre que não for rudimentar, que não for simplesmente animal" (BATAILLE, 1987, p.28). Logo, para se desvencilhar da animalidade inicial e transformá-la em atividade erótica, o homem teve de trabalhar, compreender que morria, precisou passar da sexualidade livre à sexualidade envergonhada, da qual nasceu o erotismo, e esquecer que a imposição de limites é um meio para a multiplicação dos desejos lascivos mais recônditos e mais obscuros, os quais, na maioria das vezes, devem, para que a suposta ordem social seja mantida, estar sob a sombra de interditos. Como mostraremos mais adiante, a poesia de Graça Nascimento vai de encontro a essa política de interdição e cerceamento do desejo erótico em consonância, portanto, com 
outros autores e autoras que, em épocas distintas da história da humanidade, registraram, nas mais diversas formas artísticas, um interesse pelas práticas e representações sexuais.

No entanto, é preciso registrar que esse interesse não foi suficiente para enobrecer o tema e "a representação erótica foi e ainda costuma ser marotadamente colocada em nível das coisas não sérias (ou demasiadamente sérias), rebaixada ao nível das manifestações imorais, irrelevantes, apolíticas, menores, desagregadoras, perigosas, ou incentivadas até uma saturação restritiva" (DURIGAN, 1985, p.11). De acordo com Moraes (2015), dentre os obstáculos que inviabilizaram, durante muito tempo, o reconhecimento e a valorização da produção erótica, no cenário literário brasileiro, estão dois:

\begin{abstract}
O primeiro excede o âmbito nacional e diz respeito à expressão moderna do erotismo literário que, até pouco tempo, foi objeto de reiteradas proibições nas sociedades ocidentais, sendo não raro produzido e difundido na clandestinidade. Por certo, essa característica não teria sido diferente no Brasil, cuja história traz fortes marcas da moral cristã e do jugo patriarcal que, aliados a outras formas de repressão, também precipitaram mecanismos eficazes de censura às manifestações licenciosas. $\mathrm{O}$ segundo obstáculo [diz respeito ao fato de que,] por se manter 'desorganizados', talvez em resposta as dispositivos repressivos, nossos textos obscenos foram sendo empurrados para as margens dos círculos letrados, o que adiou a constituição de um conjunto, tal como foi possível em outras culturas (MORAES, 2015, p. 22).
\end{abstract}

Em virtude de tais obstáculos, parece-nos que o erotismo foi, não só no Brasil, algo de que se falava apenas em espaços restritos, o que o obrigou a refugiar-se no domínio do implícito, do não-dito, das entrelinhas, do sussurro. Estes, depois, passaram a ser tomados como suas características absolutas, mas não impediram a manifestação dos ímpetos sexuais, já que, de há muito, a humanidade se interessa por saberes sobre o sexo, os quais foram o escopo das mais diversas formas de arte, em especial da literatura (DURIGAN, 1985).

No caso específico do texto literário, esse é, há muito tempo, uma fonte inesgotável de ensinamento e de encantamento e, sendo erótico, ele passa a ser "um tecido, um espetáculo, uma textura das relações significativas que no seu conjunto configura e entrelaça papéis e características com a finalidade de mostrar uma representação cultural, particular, singular da sexualidade" (DURIGAN, 1985, p.38). Esta, ao ser representada literariamente, apresenta características singulares que dependem da época, dos valores, dos grupos sociais, das particularidades do/a escritor/a, das características da cultura em que ela, a sexualidade, encontra-se engendrada. Não obstante, cabe ressaltarmos que não é apenas através dos canais da sexualidade explícita que Eros se faz ouvir: 


\begin{abstract}
Aliás, o segredo de seu poder parece residir exatamente nessa maleabilidade: o erotismo deriva de impulsos sexuais, mas é capaz de ultrapassá-los e de se revelar mesmo em casos de extrema sublimação dos impulsos sexuais. [...] Afinal, como deus que varia e multiplica as espécies vivas, Eros deve ser também múltiplo, vário em seu constante movimento. Fugidio e subterrâneo, ele permanecerá invulnerável aos controles e leis sociais: onde houver vida humana, haverá sempre a ameaça da desordem erótica, a promessa de resgate da totalidade perdida, o silêncio hipnótico do deus (BRANCO, 1987, p. 14).
\end{abstract}

Os impulsos de Eros abrangem, ainda de acordo com Branco (1987), as visões alucinadas dos místicos, o canto dos poetas, as imagens abstratas de um pintor, o diálogo uterino entre mãe e filho, os mitos sobre a criação e fim do mundo, o que pode nos levar a ver o erotismo como um tema que apresenta algumas variações, as quais vão desde o mero olhar, a mais delicada sensualidade, o erotismo espiritual e mesmo religioso, o relacionamento sexual específico até o sexo propriamente dito. Acerca das faces de Eros, Andrade (2008) pontua:

\begin{abstract}
Em literatura, o poético pode se constituir mediante o discurso erótico que recorre ao que a moral tradicional tem considerado palavrão e, também, pode ser inscrito através da alusão, isto é, através de imagens. A literatura erótica - como, aliás, toda literatura - é uma representação cultural. Um complicador dessa discussão é o fato de o texto erótico ser representação de um jogo - o jogo erótico - que já é, em si, uma representação cultural. Qualquer que seja a forma de expressão utilizada no texto erótico, ai estarão representados [...] valores culturais da sociedade. Assim, o erotismo no texto literário, seja tecido através de um discurso metafórico, seja através de uma linguagem indecente, visa à construção de uma imagem da sedução, de um estado de excitação sexual, de um desejo (ANDRADE, p.35-36).
\end{abstract}

Muitas são, pois, as formas como Eros, ao longo dos tempos, se mascara. No âmbito da literatura, o erotismo, mais do que tema, configura-se como um modo de pensar não o sexo, mas a partir do sexo de forma que "Ao submeter a referência sexual a uma estilização, o escritor fica livre para transformar o sexo num observatório a partir do qual se pode contemplar qualquer prisma do universo, incluindo o que está aquém ou além do próprio sexo"(MORAES, 2015, p.27). Nesse caso, acreditamos que o estudo da poesia de Graça Nascimento pode contribuir para que conheçamos mais um pouco das facetas desse deus que "multiplica e varia as espécies vivas", sobretudo a partir de uma voz autoral no feminino, até porque, como acentua Moraes (2008), sobre a produção erótica em nosso país, seja a mais erudita, seja a mais popular, tem se 
voltado pouco interesse, o que é decorrente de interditos sociais contra os quais, acreditamos, se insurge a lírica de Graça Nascimento que segue certa liberdade formal, pois cultiva uma miríade de formas que vão da mais clássica, como o soneto, até às mais populares, como as décimas, os motes, os mourões.

No âmbito temático, Graça Nascimento não é, exclusivamente, uma poetisa erótica. Ainda que alguns vocábulos eróticos permeiem certos poemas, o desejo erótico não é o tema central de sua obra. Não o é nem no primeiro nem no segundo livro, ainda que seja um dos aspectos mais relevantes de sua obra tendo em vista a forma como ele se encontra textualizado em seus poemas. A lírica de Graça Nascimento, em linhas gerais, segue duas direções: de um lado, nota-se certo engajamento político por meio da qual a poetisa se volta para uma reflexão acerca da opressão por que passam certos grupos minoritários, em especial as mulheres; do outro, temos a vertente lírico-amorosa em que se nota a exteriorização dos sentimentos mais recônditos, em especial o amor e a dor decorrente de amar. Nessa última linha, inserem-se, pois, os poemas de cunho erótico, os quais têm conferido à Graça Nascimento certa notoriedade.

Em Na nudez da poesia, publicado em 1991, o sintagma nominal "nudez", se aponta para o campo do desejo, do erotismo, também, uma vez lido o conjunto de poemas que compõem a obra, revela que o sentido mais adequado que podemos emprestar a tal vocábulo é o de despido, despojado. Assim, podemos dizer que, já nesse primeiro livro, Graça Nascimento constrói uma poesia que procura despir-se de pudores, despojar-se da hipocrisia social e, assim, poder falar do que lhe "vier à telha". Em sua obra, há poema que falam de amor, de sexo, de desejo, mas também da natureza, dos filhos, das injustiças sociais, da liberdade, do lugar da mulher em uma sociedade machista. Enfim, de assuntos os mais diversos que permeiam a vida de alguém que deseja converter o seu ser e estar no mundo em poesia.

Contudo, interessam-nos os poemas de dicção erótica em virtude do que já aludimos na introdução deste texto, isto é, a necessidade de compreender a representação do erotismo na literatura brasileira produzida por mulheres. Assim, o primeiro poema sobre o qual nos voltamos é Epitáfio de um morto-vivo:

\author{
Sepultaram teu corpo \\ Que gemia no meu \\ Ficaram meus gemidos \\ Ansiando os teus \\ (NASCIMENTO, 1991, p. 42)
}

De início, o título serve-nos como primeira chave de interpretação. Por epitáfio, 
entendemos as frases escritas em túmulos em homenagens a entes queridos que não mais existem porque estão mortos. O poema de Graça Nascimento insere-se, portanto, nessa tradição discursiva de uma escrita-epitáfio. Notemos que ele não apresenta pontuação, embora merecesse. Talvez, um ponto ao final do segundo verso, onde caberia também um ponto e vírgula, e outro ponto final no último verso, de maneira que, assim, o poema pode ser dividido em dois períodos. O primeiro composto pelos dois primeiros versos fala do que não mais existe: o corpo sepultado, metonímia do amado ausente, da separação dos corpos. O segundo período, por sua vez, que é composto pelo terceiro e quarto versos, diz de quem fica: o sujeito lírico e sua ardente saudade. Mas, para que pontuar o que já não mais existe? O que, sendo matéria, já em si mesmo encerra o seu próprio fim? Logo, se a morte, aquilo de que, aparentemente o poema fala, é algo sobre o qual não temos controle, não seria a existência de pontuação que iria prendê-la, contê-la. A morte, assim como o desejo, tema central do poema, não se prende a amarras. Por isso, tal qual o próprio poema, carece sempre de pontuação.

Se, comumente, se nota certo tom elegíaco nos epitáfios, porque estes encerram um lamento pela morte de outrem, o epitáfio construído por Graça Nascimento é de base erótica. Nele não se lamenta o sepultamento de um corpo, mas, sim, o fato de esse corpo não ser mais a fonte de prazer que alimentava os gemidos do eu lírico. Ou seja, lamenta-se a castração do desejo, ação essa simbolizada pelo verbo "sepultar". Sepultado o corpo, morto, entretanto, não está o desejo. Este, solitário, ainda existe e não arrefeceu, como atesta o verbo "ansiar" em sua forma gerundial a conotar a ideia de um processo que não se encerrou porque em curso ainda.

A tristeza que permeia o poema advém, portanto, da impossibilidade de correspondência dos gemidos. Talvez então o paradoxo presente no título do poema. A expressão "morto-vivo" pode remeter a alguém ou algo que, não existindo enquanto matéria, a acreditar-se que a morte de que trata o poema é realmente física e não simbólica, mantém-se presente enquanto saudade, que é o que fica do que não mais fica. Todavia, se lembrarmos que, em sentido figurado, o verbo sepultar com que se inicia o primeiro verso do poema significa esconder, ocultar e está na terceira pessoal do plural, condição para a indeterminação do sujeito sintático, podemos depreender que esse sepultamento é, metaforicamente, a separação entre os amantes, a qual aconteceu à revelia deles. Logo, o objeto do desejo vive, mas está morto porque impossibilitado de manter-se ligado ao eu lírico de viver o que poderia ter sido, mas não foi.

Nesse caso, o sepultamento aqui é o correlato de interdição. Por isso, sendo um epitáfio, o poema configura-se não apenas como uma homenagem a um morto, mas funciona como lugar de memória para que esse que se foi permaneça existindo no monumento que lhe foi erguido e que é o próprio poema. No corpo do poema, há a inscrição de um outro corpo, o 
do amante, que precisou ser apagado, sepultado, mas não esquecido. Há que se notar também que, sendo a voz lírica feminina, ela lamenta a perda do amado, mas não castra em si o desejo de amar. Aliás, parece-nos que o luto a ser vivenciado vai potencializar esse desejo, pois os gemidos permanecem na busca do que não mais há: alguém que os aplaque.

Se lembramos que vivemos em uma sociedade que dita as normas de conduta para o feminino e lhe estabelece rígidos códigos comportamentais, entendemos que, a seguir tais códigos, o eu lírico deveria, com a morte/separação do amado, cessar todo e qualquer desejo. Mas isso não acontece: a morte não lhe castra os desejos. Intensifica-os tanto que há no poema a reiteração de termos muito próximos (gemia e gemidos), os quais remetem, diretamente, ao campo do desejo. Vejamos que os gemidos a que se refere o eu lírico não são o lamento doloroso ante uma perda, mas são, nas duas ocorrências, permeados de uma carga erótica e sensual. Os gemidos prefiguram, portanto, a saudade dos momentos íntimos que não poderão mais ser vividos. Nesse caso, o poema parece ser a última homenagem (ou queixa) a quem tanto prazer deu ao eu lírico. Como homenagem erótica, vemos também o poema abaixo de título bastante singular que, talvez, seja o mais conhecido e foi, inclusive, musicado por Flaira Ferro:

\author{
A ROLA DO MEU AMADO \\ Essa rola singular do meu amado \\ Tão igual e diferente das demais \\ Entra em mim com a sinfonia de alguns ais \\ Me mostrando o lado santo do pecado \\ Quando cresce no crescer da minha entrega \\ E endurece para entrar no paraíso \\ Abro as portas sem temor e sem juízo \\ $\mathrm{E}$ ao amor nada mais a vida nega \\ Sedutora e atrevida me domina \\ Dominada em meu poder que lhe fascina \\ Entra e sai até me ver cair vencida \\ No prazer de entregar e possuir \\ Num só ato a delicia de existir \\ Ao senti-la me regando com a vida \\ (NASCIMENTO, 1991, p.43)
}

A guiarmo-nos pelo título, somos levados a pensar que o poema acima se ergue como um monumento à rola do amado que se singulariza ante a outras. Se a tradição lírica em nosso país tem sido erguida à base dos louvores ao corpo da mulher, Graça Nascimento muda um pouco o curso desse discurso e elege o corpo masculino como objeto de contemplação e desejo de sua poesia. Isso é bastante transgressor, pois é o corpo masculino, e não o feminino, como 
se acostumou a fazer nossa tradição poética, que serve como meio e matéria do processo de criação literária, processo esse que é comandado por uma mulher. Talvez, possamos dizer que o poema, em si, dada a rigidez da forma poética escolhida, pode ser metonímia do próprio membro viril do ser amado. Singular como o próprio soneto, essa forma rigorosa de convenção poética, a rola do amado se eterniza no poema.

Entretanto, se o poema é dedicado à rola do amado, percebemos que o texto também fala do próprio eu lírico, de seu desejo, de sua necessidade de gozar. Afinal, "o eu, ao falar do outro, fala também de si, enquanto opção particular pela escolha desse outro" (SECCHIN, 1985, p.44). Nesse caso, o texto todo parece ser o discurso da satisfação sexual que a rola do amado propicia ao eu lírico feminino. Talvez aí a sua diferença em relação às demais. Mais do que uma ode ao falo do amado, o poema se configura como um canto feminino pelo direito de dizer que gosta de sexo, essa "sinfonia de alguns ais" e de rola, assim como de evidenciar que não se sente culpada por transar, porque nisso está "o lado santo do pecado". Aqui, notamos que a voz lírica se põe como senhora de si, de seus desejos e vontade tanto que se permite viver as delícias do sexo sem nenhum sentimento de culpa: "Quando cresce no crescer da minha entrega/[...]Abro as portas sem temor e sem juízo/ E ao amor nada mais a vida nega". Não há, pois, receio nessa entrega. Afinal, "Num só ato [está] a delicia de existir" (NASCIMENTO, 1991, p.43). Podemos dizer que o eu lírico procura vivenciar sua sexualidade livremente sem prender aos rígidos códigos morais e comportamentais que procuram disciplinar os corpos, os desejos e à luz dos quais o próprio poema merecia condenação porque, pela linguagem e pela experiência que transfigura, estaria ferindo "a moral e os bons costumes". Aqui, notamos mais uma transgressão: Graça Nascimento desloca o feminino da posição de passividade que historicamente lhe foi legada, e confere a ele o lugar de sujeito ativo no jogo erótico.

Existe, portanto, em todo o poema um jogo de sedução que aponta para relações que não são assimétricas no campo da sexualidade. Ou seja, se a rola do amado seduz, o eu lírico também a atrai: "Sedutora e atrevida me domina/ Dominada em meu poder que Ihe fascina" (NASCIMENTO, 1991, p.43). A experiência sexual, aqui, não é uma via de mão única em que apenas uma das partes envolvidas goza. Culturalmente o feminino existe para servir ao masculino. Graça Nascimento vai de encontro a esse pensamento machista e põe a relação sexual como algo que envolve "o prazer de entregar e de possuir" (NASCIMENTO, 1991, p.43). Ou seja, no lugar de uma relação de dominação, existe, desde o primeiro até o último verso, a ideia de comunhão entre voz lírica e o outro de seu afeto, ainda que objetificado por uma parte do corpo: o falo. Além disso, notamos um traço recorrente em boa parte dos poemas escritos por Graça Nascimento: se, conforme assinala Bataille (1980, p.14), a chave do erotismo é a 
reprodução, a poesia da poetisa em análise diverge dessa prerrogativa, pois, em sua lírica, há a independência do gozo erótico e a vivência da sexualidade sem que a reprodução seja o objetivo.

Todo o poema é uma bela metáfora do conúbio sexual no qual o sujeito feminino exerce papel relevante porque não só objeto de desejo, mas sujeito desejante que não está simplesmente a serviço das vontades sexuais masculinas, mas, pelo contrário, tem o masculino como objeto de desejo e a serviço do seu (da voz lírica) prazer: "Entra e sai até me ver cair vencida". O sexo se apresenta, portanto, como marca da delícia de existir. Logo, é algo tão importante e vital que chega a ser sagrado tanto que o último verso, metáfora do gozo feminino, se fecha reafirmando o prazer que o feminino tem de ser regada pelo masculino: "Ao senti-la me regando com a vida", e, portanto, receptáculo da semente (sêmen) masculina que é acolhida não para fins reprodutivos, mas, simplesmente, porque é prazeroso banhar o corpo no leite de onde a vida emana. Ou seja, pode-se vivenciar o orgasmo sem riscos, dissociado da reprodução. Por tal aspecto, o do prazer pelo prazer, o poema se configura como erótico e põe-se “indiferente à perpetuação da vida, à reprodução, constituindo-se prazer em si mesmo" (ANDRADE, 2008, p.45).

Nesse sentido, o discurso erótico de Graça Nascimento configura-se, de certo modo, como transgressor porque aloca o erotismo "nas veredas do princípio do prazer, dissociando-o, portanto, das tarefas reprodutivas" (ANDRADE, 2008, p.41), e coloca a autora no rol de escritores/as que "tenta(ra)m quebrar os limites impostos pela sociedade, [contrapondo-se à] falsa moralidade reinante e [a]os engenhosos mecanismos da hipocrisia" (ANDRADE, 2008, p.41). Por isso, em conjunto com outros/as autores/as em cuja obra o jogo da pulsão erótica se faz presente, a exemplo de Gilka Machado, Olga Savary, Adélia Prado, Marina Colasanti, Maria Teresa Horta, Hilda Hilst, a poesia de Graça Nascimento, ante os moralismos e conservadorismos que grassam em nossa sociedade, inquieta, pode ser vista como subversiva, perigosa porque não vê pecados na carne.

Como espaço de demarcação da vida, o gozo se mostra, no poema "A rola do meu amado", como manifestação do sagrado que, existindo em cada humano, pode conduzir ao divino. Aliás, como afirma Octavio Paz, o erotismo é a cota de Paraíso que coube ao ser humano. Por isso, o erotismo não é só esse movimento impulsionador para a vivência do quinhão que nos restou do paraíso, mas é, em virtude disso, também a exaltação da sexualidade, do desejo amoroso, como o faz Graça Nascimento em sua poesia. Ademais, acerca do consórcio entre erotismo e sagrado, na busca da unidade primordial, lembremos que, "em duas religiões marcadamente ascéticas, o budismo e o cristianismo, figura também - e de maneira proeminente 
- a união entre sexualidade e sagrado. Cada uma das religiões históricas engendrou, externa ou internamente, seitas, movimentos, ritos e liturgias nas quais a carne e o sexo são caminhos em direção à divindade" (PAZ, 1994, p.20), ainda que, dentro do Ocidente, a ideologia sobre o amor não tenha sido derivada a partir de uma tradição religiosa, como o foi no Oriente (cf. PAZ, 1994).

Assim, entendemos por que o poema é uma espécie de cântico de devoção ao membro do amado. Em outras palavras, a rola do amado mostra-se como objeto igualmente sagrado porque permite, no carnal, a comunhão com o divino que se presentifica no gozo sexual: "Ao senti-la me regando com a vida". Ao contrário do senso comum e de determinados setores conservadores que procuram separar sexo e sagrado, como se fossem esferas antípodas, Graça Nascimento os une em um só corpo, em uma só voz. O corpo é, pois, espaço da presença do sagrado e não expiação de pecados, razão por que deve se abrir ao desejo, deixar-se penetrar e gozar "sem temor e sem juízo". E isso é dito em uma linguagem franca, sem pudor porque quem o diz se coloca como senhora de si, de seu corpo, mas, sobretudo, de seus próprios prazeres. Em outras palavras, o erotismo que emana da lírica de Graça Nascimento não é fruto de carências, mas da plena e efetiva satisfação sexual. Esse protagonismo feminino no campo do desejo e a reafirmação do seu direito de gozar bem como a presença do falo como objeto de desejo, elementos presentes no poema anterior, são reiterados no poema abaixo:

\section{ROLANDO EM ROLAS}

Cada uma com um quê particular Todas foram num momento especiais Nelas li as partituras colossais De gemidos que espalhei por todo ar

Cada uma conseguiu me deflorar Pois a todas dei momentos virginais Umas menos, já outras tiveram mais Conseguindo o que souberam conquistar

Uma a uma me levaram em viagens Me mostrando nova cor novas paisagens E deixando o meu caminho iluminado

Mas preciso confessar em poesia Se eu pudesse todas elas trocaria Pela rola singular do meu amado. (NASCIMENTO, 2004, p.160)

Publicado em 2004, no livro Outras Graças, reunião de textos em prosa e em verso da 
autora, Rolando em rolas vem reafirmar, passada mais de uma década de publicação do primeiro livro ao qual pertencem os primeiros poemas analisados, que a voz lírica em Graça Nascimento permanece em plena atividade erótica, que o desejo que serve de esteio para a sua lírica não arrefeceu e que esse interim entre um e outro livro foi de intensa aprendizagem erótica porque em sua vida outras experiências sexuais foram vividas, outras rolas aninharam-se em seu corpo: "Cada uma com um quê particular/Todas foram num momento especiais". Corpo esse que se abre em consentimento às delícias do sexo: "Pois a todas dei momentos virginais/ Umas menos, já outras tiveram mais" (NASCIMENTO, 2004, p.160) e não se configura como espaço de aprisionamento, mas de emancipação erótica. Destaquemos, ainda, que, no poema, a mulher exerce um papel ativo dentro do ato amoroso, visto que, embora tenha tido vários parceiros, metonimicamente representados pelo vocábulo "rola" no plural, eles tiveram dela apenas "O que souberam conquistar", revelando uma não passividade do feminino que, se se deixa possuir, o faz porque quer e não porque se põe submissamente à vontade do masculino. Ou seja, a mulher que fala no poema não se anula e não se põe como mero objeto de satisfação do apetite sexual masculino. No jogo erótico, ela se coloca como copartícipe.

Nesse poema, que, tal qual o anterior, se ergue como um monumento erótico, percebemos a mesma dicção lírica: a inscrição do desejo de uma voz feminina que não se furta a dizer que goza ("De gemidos que espalhei por todo ar") e que isso, o gozo e a sua verbalização via poesia, Ihe faz bem. Novamente, reafirma-se a representação de uma sexualidade que não é castrada e que não é vista como pecaminosa. Pelo contrário, nesse olhar feminino sobre o sexo, temos um discurso que o valoriza como caminho de iluminação para o ser: "Uma a uma me levaram em viagens/Me mostrando nova cor novas paisagens/ E deixando o meu caminho iluminado" (NASCIMENTO, 1991, p.43). Notamos uma perspectiva que vê o sexo como algo sagrado, como força que rege a vida porque revelação dos segredos lidos "nas partituras colossais".

Nesse percurso, se outras rolas foram importantes nesse processo erótico de aprendizagem, a que mais tocou o eu lírico foi "a rola singular do meu amado". Com esse verso, a poetisa não só reatualiza certo dito popular segundo a qual "amor de pica é o que fica", mas remete, explicitamente, ao poema escrito na década de 90 que, tal qual a rola do amado, torna-se caro à poetisa, porque o primeiro que lhe abriu os caminhos do sexo e da poesia. Por isso, a saudosa lembrança em uma obra que se dobra sobre si mesma em um diálogo vívido no que tange à poetização do gozo erótico feminino, o que de certa forma pode ser lido com representação "da liberdade conquistada pela mulher; liberdade de decidir o que fazer do seu corpo, quando fazer e com quem fazer" (ANDRADE, 2008, p.28). Em Graça Nascimento, o eros 
feminino não se faz interdição. Pelo contrário, sua poesia ergue-se sob a égide da liberdade, da liberação, do direito de poder gozar e de dizê-lo sem rubor algum. Enfim, é uma poesia que procura celebrar as alegrias da carne e daquele que, no dizer de Muchembled (2007, p.52), é "o prazer mais refinado, mais valorizado e mais importante da experiência humana: o do sexo".

\section{CONSIDERAÇÕES FINAIS}

No conjunto de poemas que têm o erotismo como escopo e dos quais trouxemos uma pequena mostra neste trabalho, percebemos que o discurso que os perpassa gravita em torno da assunção pelo direito de vivenciar o sexo, a sexualidade sem a necessidade de regulá-los e, por conseguinte, poder falar do desejo, de suas pulsões, de suas necessidades sem o fantasma da culpabilização. A poesia de Graça Nascimento é, portanto, um canto de resistência ao policiamento do desejo.

Tendo em vista que, apesar de publicados na década de 90, acreditamos que os poemas de Graça Nascimento foram gestados na década de 80, logo sua obra, assim como de muitas outras mulheres-escritoras que escreveram entre as décadas de 70 e 80, nasce da revolta/revolução cultural operada a partir da década de 60, quando, em especial no caso das mulheres, as relações de repressão e dependência são questionadas e são postos em xeque os critérios de verdade preconizados pela ideologia em vigor (CUNHA, 1999). Nesse sentido, a nosso ver, Graça Nascimento se insere no rol de mulheres que, amalgamando erotismo e criação poética, cantam, liricamente, o desejo e o prazer femininos de maneira que podemos aplicarIhes as seguintes palavras de Ria Lemaire:

\footnotetext{
Elas dizem o gozo, e, ao dizê-lo, destroem os mecanismos repressores da subjetividade feminina, dos padrões convencionais de comportamento social, tão limitativos para a mulher. Instauram a poesia/erotismo como fonte de autoconhecimento, de conhecimento do Outro e do mundo, como princípio de novas formas de solidariedade social e humana (Lemaire, 1999, p.12).
}

Em sua poesia, Graça Nascimento traz para o plano da expressão a fala de um sujeito que, secularmente, foi reprimido. Logo, temos uma voz feminina que deseja e, mais do que isso, sente a necessidade de expressar esse desejo sem medo, receio ou culpa por senti-lo e por expressá-lo. Uma voz que se afirma como poetisa e como mulher que goza. Talvez por isso é 
que as imagens eróticas em sua poesia não são nada veladas. Ela não dissimula seu desejo. Revela-o e, ao fazê-lo, eroticamente, se expõe. A voz lírica em Graça Nascimento não quer esconder o que sente, evidenciando que o feminino, em sua poesia, tem voz e é sujeito de seu desejo.

Em se tratando de desejo, a voz lírica de Graça Nascimento não tem indecisão: gozar é permitido, é desejado, é o imperativo. A dicção lírica de Graça Nascimento não canta a beleza do corpo feminino, como muitos poetas o fazem, porque ela não fala de fora, mas, sim, canta o turbilhão de desejo em que arde o feminino. Ou seja, Graça Nascimento fala de dentro e no feminino a partir de uma perspectiva que revela certa consciência de que o erótico pode ser literário e, sendo literário, assenta-se em uma ética que não recusa o prazer, mas faz dele pedra angular de sua poesia onde o principio do prazer reina descontraído e desafia "os códigos falocêntrico, derrubando o condicionamento imagístico tão zelosamente conservado durante séculos pela tradição" (CUNHA, 1999, p.162). Enfim, a lira é de Eros, mas a melodia que ela toca é feminina.

\section{Referências:}

ANDRADE, Janilto. Erotismo em João Cabral. Rio de Janeiro: Calibãn, 2008.

BATAILLE, Georges. O erotismo. Tradução de Antonio Carlos Viana. Porto Alegre: L\&PM, 1987.

BRANCO, Lúcia Castello. O que é erotismo. 2.ed. São Paulo: Brasiliense, 1987 (Primeiros Passos; 136).

CARA, Maria Salete. A poesia lírica. São Paulo: Ática, 1986. (Série Princípio; 20).

CUNHA, Helena Parente. O desafio da fala feminina ao falo falocêntrico: aspectos da literatura de autoria feminina na ficção e na poesia dos anos 70 e 80 no Brasil. In: RAMALHO, Christina (org.). Literatura e feminismo: propostas teóricas e reflexões críticas. Rio de Janeiro: Elo, 1999, p.151-171.

DAL FARRA, Maria Lúcia. Prefácio. In: MACHADO, Gilka. Poesia Completa. Organização de Jamyle Rkain. São Paulo: V. De Moura Mendonça, 2017, p. 18-49. (Selo Demônio Negro).

HEGEL, Georg Wilhelm Friedrich. Curso de Estética. vol. IV. Tradução de Marco Aurélio Werle e Oliver Tolle. São Paulo: Editora da Universidade de São Paulo, 2004. (Clássicos; 26).

MORAES, Eliane Robert. Antologia da poesia erótica brasileira. São Paulo: Ateliê Editorial, 2015.

. A erótica literária no modernismo brasileiro. In: Congresso Internacional da ABRALIC: Tessituras, Interações, Convergências. 11., 2008, São Paulo, Anais...São Paulo: ABRALIC, 2008, p. 1-6.

MUCHEMBLED, Robert. O orgasmo e o ocidente: uma história do prazer do século XVI a nossos dias. Tradução de Mônica Stahel. São Paulo: Martins Fontes, 2007.

NASCIMENTO, Graça. Na nudez da poesia. Edição da autora. 1991.

Outras Graças. Edição da autora. 2004. 
PAZ, Octavio. A dupla chama: amor e erotismo. São Paulo: Siciliano, 1994

SECCHIN, Antonio Carlos. João Cabral: a poesia de menos. São Paulo: Duas Cidades, 1985.

SOARES, Angélica. A paixão emancipatória: vozes femininas da liberação do erotismo na poesia brasileira. Rio de Janeiro: Difel, 1991.

Recebido em 24/07/2019

e aprovado em 20/09/2019. 